\title{
Impact of Different Zinc Application Methods on Yield and Yield Components of Various Wheat (Triticum aestivum L.) Cultivars
}

\author{
Usman Afzal1', Muhammad Shahid Ibni Zamir'1, Shan Mohi Ud Din 1*, Aqib Bilal2, \\ Muhammad Salahuddin', Shahid Iqbal Khan' \\ ${ }^{1}$ Department of Agronomy, University of Agriculture, Faisalabad, Pakistan \\ ${ }^{2}$ Department of Botany, University of Agriculture, Faisalabad, Pakistan \\ Email: *shanmahar788@gmail.com, Shan.mahar@uaf.edu.pk
}

How to cite this paper: Afzal, U., Zamir, M.S.I., Din, S.M.U., Bilal, A., Salahuddin, M. and Khan, S.I. (2017) Impact of Different Zinc Application Methods on Yield and Yield Components of Various Wheat (Triticum aestivum L.) Cultivars. American Journal of Plant Sciences, 8, 3502-3512. https://doi.org/10.4236/ajps.2017.813236

Received: June 7, 2017

Accepted: December 26, 2017

Published: December 29, 2017

Copyright $\odot 2017$ by authors and Scientific Research Publishing Inc. This work is licensed under the Creative Commons Attribution International License (CC BY 4.0).

http://creativecommons.org/licenses/by/4.0/

\begin{abstract}
To evaluate the impact of different zinc application methods on yield and yield components of various wheat cultivars, a field experiment was carried out at Student's Farm, Department of Agronomy, University of Agriculture Faisalabad, during winter 2014-2015. The experiment was laid out in RCBD (Randomized Complete Block Design) with factorial arrangement. In this experiment, all the treatments were replicated three times, using the net plot size of $1.8 \mathrm{~m} \times 5.0 \mathrm{~m}$. The experiment comprised of two factors. Factor A consists of two varieties: Faisalabad-2008 and Punjab-2011. While, Factor B consists of different methods of zinc application, control, zinc application in soil before planting $23 \mathrm{~kg} \cdot \mathrm{ha}^{-1}$, zinc foliar application, $4 \% \mathrm{ZnSO}_{4}$ solution at two stages (tillering and stem elongation stage). The data regarding different parameters were collected and analyzed from the crop using standard procedures. Regarding the impact of zinc application method maximum plant height at maturity $(103.6 \mathrm{~cm})$, total number of tillers $\left(564.67 \mathrm{~m}^{-2}\right)$, spike length $(10.83 \mathrm{~cm})$, number of spikelets spike ${ }^{-1}$ (19.50), number of grains spike ${ }^{-1}$ (50.36), 1000 -grain weight $(34.16 \mathrm{~g})$, biological yield $\left(11.93 \mathrm{t} \cdot \mathrm{ha}^{-1}\right)$, grain yield $(6.00$ $\left.\mathrm{t} \cdot \mathrm{a}^{-1}\right)$ and harvest index (39.25\%) were recorded in treatment where zinc was applied both in the soil before planting and by foliar application on later growth stages. Similarly, grain zinc contents $\left(33.11 \mathrm{mg} \cdot \mathrm{kg}^{-1}\right)$, grain protein contents (10.1\%) and grain carbohydrate contents (64.23\%) were also observed in the treatment where zinc was applied both in the soil before planting and by foliar application on later growth stages, which is better than all other treatments. In case of wheat varieties, Faisalabad-2008 performed better than Punjab-2011, with maximum method maximum total number of tillers $\left(460.67 \mathrm{~m}^{-2}\right)$, spike length $(9.70 \mathrm{~cm})$, number of grains spike ${ }^{-1}(48.80), 1000$-grain
\end{abstract}


weight $(33.81 \mathrm{~g})$, biological yield $\left(10.32 \mathrm{t} \cdot \mathrm{ha}^{-1}\right)$, grain yield $\left(5.0 \mathrm{t} \cdot \mathrm{ha} \mathrm{a}^{-1}\right)$ and harvest index (33.93\%). It is concluded that sowing of wheat cultivar Faisalabad-2008 + application of zinc in soil before planting with foliar application at later stages (tillering and stem elongation stage) of wheat could give better results in terms of yield.

\section{Keywords}

Wheat, Zinc, Application Methods, Zinc Contents

\section{Introduction}

Wheat is the cereal crop which ranks first among all the cereal crops and also the most important crop of Pakistan. It is also the staple food for most of population in Pakistan. Cultivation of wheat directly or indirectly affects the prosperity of the country. The area under wheat cultivation during the year 2014-2015 was 9180 thousand hectares, from which 24,478 thousand tons of wheat was produced [1]. The average yield of the wheat is very low than that of its potential; imbalanced crop nutrition is most important factor which contributes towards the decrease in yield among all of the above mentioned factors [2]. The production of the wheat could easily be increased in present situation just by increasing the yield per unit area. The major reason that contributes towards the lower yields is imbalanced nutrition of the crop. Continuous cropping on same piece of land without showing any interest towards the nutrient management results in decrease of the organic matter in the soil which ultimately results in the micronutrients deficiency [3]. Different crops have different requirements of macro and micronutrients to complete their life cycle [2].

The cereals which most commonly suffer from deficiency of zinc are wheat and rice [4]. In Pakistan, the zinc is applied to rice crop in the areas where there rice-wheat cropping system is followed, but application of zinc is rare in the areas where cotton-wheat cropping system is followed. Furthermore, the reason behind application of zinc in rice-wheat cropping sing system is that rice crop shows deficiency of zinc and also with application of zinc to rice in flooded conditions of soil significantly increases its yield [5] and [6]. There is very less study that had been done on indexing of zinc and its application in areas where cotton-wheat cropping system is followed.

Deficiency of micronutrients in crop production is spreading worldwide. It has affected the one-half population of the developing world in which people mainly depend upon few staple food crops like, maize, rice and wheat. About $50 \%$ of total cereal crops are growing on those soils which are deficient in micronutrients. Out of 16 essential elements, the elements which are included in the class of trace elements are zinc, copper, boron, iron, magnesium, chlorine, molybdenum and nickel. These elements perform vital role in the growth of crop 
plants. One of the most important nutrients among the above mentioned elements is zinc. Zinc is the nutrient which performs its role in all six classes of enzymes i.e., ligases, isomerases, lyases, hydrolase, transferases and oxidoreductases [7].

Under current $\mathrm{Zn}$ malnutrition scenario, to get higher concentrations of zinc in grain, higher amounts of zinc application may be recommended. But on the other hand, ranges of optimum and toxicity of zinc element and the rotation that was followed are of extreme importance to make any recommendation. The grain yield and concentration of zinc in grain is highly influenced by the method which is adopted to apply zinc [8]. Now, there is need of studies to find out farmer friendly method to apply $\mathrm{Zn}$ to attain high adoptability.

From the above discussion, the goal towards which my research will be carried out is as follows:

- To determine the best method for application of zinc on different wheat varieties for higher grain yield.

\section{Materials and Methods}

\subsection{Experiment and Treatments}

A field experiment to evaluate the impact of different zinc application methods on yield and yield components of various wheat (Triticuma estivum L.) cultivars, The study was conducted at the Agronomic Research Area, University of Agriculture, Faisalabad (latitude $31^{\circ} \mathrm{N}$, longitude $73^{\circ} \mathrm{E}$ and altitude $184.4 \mathrm{~m}$ asl), Pakistan, during Rabi season 2014-2015.

This experiment was laid out under Randomized Complete Block Design with factorial arrangement. All the treatments were replicated three times. Gross plot size was $1.5 \mathrm{~m} \times 6 \mathrm{~m}$ and net plot size was $1.5 \mathrm{~m} \times 5 \mathrm{~m}$. Row to row distance was $22.5 \mathrm{~cm}$. The treatments which were used in this experiment are given below.

Factor A: (Varieties)

$\mathrm{V}_{1}=$ Faislabad -2008

$\mathrm{V}_{2}=$ Punjab-2011

Factor B: (Zinc application methods)

$\mathrm{Z}_{1}=$ Control

$\mathrm{Z}_{2}=$ Soil application before planting @ $23 \mathrm{~kg} \cdot \mathrm{ha}^{-1}$

$\mathrm{Z}_{3}=$ Foliar application @ 0.4\% Zn solution at two stages (tillering and stem elongation)

$\mathrm{Z}_{4}=$ Soil application before planting @ $11.5 \mathrm{~kg} \cdot \mathrm{ha}^{-1}+$ foliar Application @ $0.4 \% \mathrm{Zn}$ solution at two stages (tillering and stem elongation)

\subsection{Crop Husbandry}

Crop sown with the help of hand drill on November 29, 2010 using seed rate of $125 \mathrm{~kg} \cdot \mathrm{ha}^{-1}$ in $22.5 \mathrm{~cm}$ spaced rows. Fertilizers were applied at 100-90-75 $\mathrm{N}-\mathrm{P}_{2} \mathrm{O}_{5}-\mathrm{K}_{2} \mathrm{O} \mathrm{kg} \cdot \mathrm{ha}^{-1}$ using urea $(46 \% \mathrm{~N})$, diammonium phosphate $(18 \% \mathrm{~N}, 46 \%$ $\left.\mathrm{P}_{2} \mathrm{O}_{5}\right)$ and sulfate of potash $\left(50 \% \mathrm{~K}_{2} \mathrm{O}\right)$. Whole of the $\mathrm{P}, \mathrm{K}$ and one third of the $\mathrm{N}$ 
was applied as basal dose. Remaining $\mathrm{N}$ was applied with $1^{\text {st }}$ and $2^{\text {nd }}$ irrigation in equal splits. Selected herbicide (Atlantis (iodo + mesosulfuron) at $14.4 \mathrm{~g}$ a.i. ha ${ }^{-1}$ ) was applied as early post emergence to control weeds. In total, four irrigations (each of 3 acre inches) were applied to the crop during the growth period in addition to soaking irrigation of four acre inches. Crop was harvested on $24^{\text {th }}$ of April, 2015 at harvest maturity and was threshed to record the yield and other related traits.

\subsection{Weather Data}

All weather data of crop season was obtained from Agro-metrological Observatory, Department of Crop Physiology, University of Agriculture, Faisalabad, Pakistan situated $\sim 200 \mathrm{~m}$ away from the experimental site. The weekly main values of relative humidity, rainfall, and temperature are given in Figure 1.

\section{Results and Discussion}

\subsection{Total Numbers of Tillers $\left(\mathrm{m}^{-2}\right)$}

From the data presented in Table 1, it is concluded that there was a significant difference between both varieties in case of total number of tillers produced. Maximum number of tiller $\left(460.67 \mathrm{~m}^{-2}\right)$ was produced by Faisalabad-2008 and minimum number of tiller $\left(427.25 \mathrm{~m}^{-2}\right)$ was produced by Punjab-2011.

Table 1. Growth and yield related parameters of different wheat cultivar as influenced by zinc.

\begin{tabular}{|c|c|c|c|c|c|c|c|c|}
\hline & $\begin{array}{l}\text { Total no. of } \\
\text { tillers }\left(\mathrm{m}^{-2}\right)\end{array}$ & $\begin{array}{c}\text { No. of } \\
\text { spikelets spike }\end{array}$ & $\begin{array}{c}\text { No. of } \\
\text { grains spike }^{-1}\end{array}$ & $\begin{array}{l}\text { 1000-grain } \\
\text { weight }(\mathrm{g})\end{array}$ & $\begin{array}{c}\text { Biological } \\
\text { yield } \\
\left(\mathrm{t} \cdot \mathrm{ha}^{-1}\right)\end{array}$ & $\begin{array}{c}\text { Grain } \\
\text { yield } \\
\left(\mathrm{t} \cdot \mathrm{ha}^{-1}\right)\end{array}$ & $\begin{array}{l}\text { Grain zinc } \\
\text { contents } \\
\left(\mathrm{mg} \cdot \mathrm{kg}^{-1}\right)\end{array}$ & $\begin{array}{c}\text { Grain } \\
\text { protein } \\
\text { contents (\%) }\end{array}$ \\
\hline $\mathrm{V}_{1}=$ Punjab-2011 & $427.25 \mathrm{~B}$ & $18.75 \mathrm{~A}$ & $43.32 \mathrm{~B}$ & $26.29 \mathrm{~B}$ & $10.05 \mathrm{~B}$ & $4.24 \mathrm{~B}$ & $25.30 \mathrm{~B}$ & $9.51 \mathrm{~B}$ \\
\hline $\mathrm{V}_{2}=$ Faisalabad-2008 & $460.67 \mathrm{~A}$ & $17.58 \mathrm{~B}$ & $48.80 \mathrm{~A}$ & $33.81 \mathrm{~A}$ & $10.32 \mathrm{~A}$ & $5.00 \mathrm{~A}$ & $25.68 \mathrm{~A}$ & $9.80 \mathrm{~A}$ \\
\hline HSD value & 31.60 & 0.66 & 2.30 & 1.81 & 0.46 & 0.44 & 0.25 & 0.22 \\
\hline $\mathrm{Z}_{1}=$ Control & $352.33 \mathrm{C}$ & $16.50 \mathrm{C}$ & $42.38 \mathrm{~B}$ & $26.53 \mathrm{~B}$ & $8.38 \mathrm{D}$ & $4.00 \mathrm{~B}$ & $18.53 \mathrm{D}$ & $9.20 \mathrm{C}$ \\
\hline $\mathrm{Z}_{2}=$ Soil & $410.17 \mathrm{BC}$ & $17.83 \mathrm{~B}$ & $45.03 \mathrm{~B}$ & $29.86 \mathrm{~B}$ & $9.63 \mathrm{C}$ & $4.16 \mathrm{~B}$ & $22.76 \mathrm{C}$ & $9.46 \mathrm{BC}$ \\
\hline $\mathrm{Z}_{3}=$ Foliar & $448.67 \mathrm{~B}$ & $18.83 \mathrm{AB}$ & $46.46 \mathrm{AB}$ & $29.65 \mathrm{~B}$ & $10.78 \mathrm{~B}$ & $5.03 \mathrm{~B}$ & $27.57 \mathrm{~B}$ & $9.68 \mathrm{AB}$ \\
\hline$Z_{4}=$ Soil + Foliar & $564.67 \mathrm{~A}$ & $19.50 \mathrm{~A}$ & $50.36 \mathrm{~A}$ & $34.16 \mathrm{~A}$ & $11.93 \mathrm{~A}$ & $6.00 \mathrm{~A}$ & $33.11 \mathrm{~A}$ & $10.10 \mathrm{~A}$ \\
\hline HSD value & 60.54 & 0.127 & 4.42 & 3.46 & 0.89 & 0.85 & 0.49 & 0.43 \\
\hline $\mathrm{V}_{1} \times \mathrm{Z}_{1}$ & $361.00 \mathrm{~cd}$ & $16.67 \mathrm{~cd}$ & $39.63 \mathrm{~d}$ & $25.20 \mathrm{~d}$ & $8.26 \mathrm{c}$ & $3.13 \mathrm{c}$ & 18.46 & 9.13 \\
\hline $\mathrm{V}_{1} \times \mathrm{Z}_{2}$ & $406.33 \mathrm{~b}-\mathrm{d}$ & $18.66 \mathrm{a}-\mathrm{c}$ & $41.60 \mathrm{~cd}$ & $26.26 \mathrm{~d}$ & $9.50 \mathrm{bc}$ & $3.93 \mathrm{bc}$ & 22.50 & 9.40 \\
\hline $\mathrm{V}_{1} \times \mathrm{Z}_{3}$ & $440.67 \mathrm{~b}-\mathrm{d}$ & $19.67 \mathrm{a}$ & $42.50 \mathrm{~b}-\mathrm{d}$ & $24.12 \mathrm{~d}$ & $10.63 \mathrm{ab}$ & $4.53 \mathrm{a}-\mathrm{c}$ & 27.30 & 9.60 \\
\hline $\mathrm{V}_{1} \times \mathrm{Z}_{4}$ & $501.00 \mathrm{~b}$ & $20.00 \mathrm{a}$ & $49.56 \mathrm{ab}$ & $29.56 \mathrm{~b}-\mathrm{d}$ & $11.80 \mathrm{a}$ & $5.36 \mathrm{a}$ & 32.96 & 9.93 \\
\hline $\mathrm{V}_{2} \times \mathrm{Z}_{1}$ & $343.67 \mathrm{~d}$ & $16.33 \mathrm{~d}$ & $45.13 \mathrm{a}-\mathrm{d}$ & $27.86 \mathrm{~cd}$ & $8.50 \mathrm{c}$ & $4.86 \mathrm{ab}$ & 18.60 & 9.26 \\
\hline $\mathrm{V}_{2} \times \mathrm{Z}_{2}$ & $414.00 \mathrm{~b}-\mathrm{d}$ & $17.00 \mathrm{~b}-\mathrm{d}$ & $48.46 \mathrm{a}-\mathrm{c}$ & $33.46 \mathrm{a}-\mathrm{c}$ & $9.76 \mathrm{bc}$ & $4.40 \mathrm{a}-\mathrm{c}$ & 23.03 & 9.53 \\
\hline $\mathrm{V}_{2} \times \mathrm{Z}_{3}$ & $456.67 \mathrm{bc}$ & $18.00 \mathrm{a}-\mathrm{d}$ & $50.43 \mathrm{a}$ & $35.16 \mathrm{ab}$ & $10.93 \mathrm{ab}$ & $5.53 \mathrm{a}$ & 27.83 & 9.76 \\
\hline $\mathrm{V}_{2} \times \mathrm{Z}_{4}$ & $628.33 \mathrm{a}$ & $19.00 \mathrm{ab}$ & $51.16 \mathrm{a}$ & $38.76 \mathrm{a}$ & $12.07 \mathrm{a}$ & $5.20 \mathrm{ab}$ & 33.26 & 10.26 \\
\hline HSD value & 103.9 & 2.18 & 7.58 & 5.95 & 1.53 & 1.46 & 0.84 & 0.73 \\
\hline
\end{tabular}

Means sharing same letter do not differ significantly. 


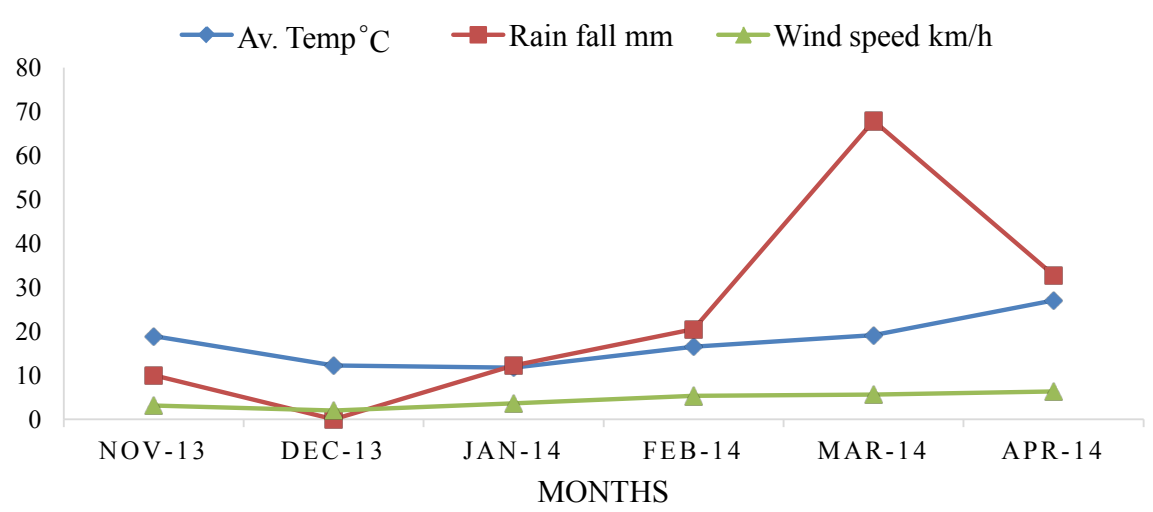

Figure 1. Weather data, 2014-15.

In case of zinc levels, there was non-significant effect that was noticed. Maximum number of tiller $\left(564.67 \mathrm{~m}^{-2}\right)$ was produced where zinc was applied both in soil before and foliar application at later stages followed by $\left(448.67 \mathrm{~m}^{-2}\right)$ where zinc was applied only by foliar application method and minimum number of tiller (352.33) was produced in plots where no zinc was applied.

The interactions were significant. Maximum numbers of tillers $\left(628.33 \mathrm{~m}^{-2}\right)$ were produced in plots where wheat variety Faisalabad-2008 was sown and zinc was applied in both sowing and foliar application method, followed by (501.0 $\mathrm{m}^{-2}$ ) the plots where Punjab-2011 was sown and zinc was applied both in soil before planting and foliar application at later growth stages. Minimum number of tiller $\left(343.67 \mathrm{~m}^{-2}\right)$ was produced where Faisalabad-2008 was sown and no zinc was applied. These results are in line to the findings made by [9] and [10] which reported that application of zinc has a very little effect on total numbers of tillers produced by wheat.

\subsection{Number of Spikelets Spike-1}

Spikelet per spike is important factor that directly contributes towards the better yield of wheat crop. Due to its direct effect on number of grains per spike, it directly affects the grain yield of any wheat plot.

Data which is presented in table shows that there is a significant difference noticed in spike length of varieties used in this experiment. Maximum number of spikelets per spike (18.75) was produced by Punjab-2011 and minimum number of spikelets per spike (17.58) was produced by Faisalabad-2008.

From Table 1, it can be seen that there is also significant relationship between zinc application methods in case of number of spikelets per spike. Maximum number of spikelets per spike (19.50) was produced in plots where zinc was applied in both soil before planting and foliar application on later stages followed by (18.83) where zinc is applied through foliar application, (17.83) where zinc was applied in soil before planting of crop and minimum number of spikelets per spike was produced in plots where no zinc was applied.

In case of interactions, there was also significant difference observed between wheat varieties and zinc application method. Maximum number of spikelets per 
spike (20.00) was produced by Punjab-2011 in plots where zinc was applied in both soil before planting and foliar application on later stages followed by (19.67) by Punjab-2011 in plots where zinc is applied through foliar application, (19.00) by Faisalabad-2008 in plots where applied in both soil before planting and foliar application and minimum number of spikelets per spike (16.33) was produced by Faisalabad-2008 in plots where there zinc was not applied.

Zinc is also involved in many plant processes including biomass accumulation (Kaya and Higgs, 2002; Cakmak, 2008), pollen viability fertilization and it is essential in tryptophan synthesis that is an originator in creation of indole-3-acetic acid. They also describes that zinc has satisfactory effects on metabolism of plant which might be responsible for greater metabolites accumulation in reproductive organs (Kaya and Higgs, 2002; Panday et al., 2006). These results are in line to the findings that were made by Ali et al. (2008). He reported that application of zinc in form of zinc sulfate on wheat significantly enhances number of spikelets per spike of wheat.

\subsection{Number of Grains Spike ${ }^{-1}$}

The results calculated from means value are presented in table. From these results it is clear that there is a significant variation is present among means of wheat varieties in case of number of grains per spike. Maximum number of grains per spike (48.80) was recorded in Faisalabad-2008 and minimum number of grains per spike (43.32) was produced by Punjab-2011.

In case of zinc application method significant difference among means was noticed. Maximum number of grains per spike (50.36) was recorded in the plots where zinc was applied both in soil before planting and foliar application on later stages, followed by (46.46) in plots where zinc was applied through foliar application, (45.03) in plots where zinc was applied in soil before planting of wheat crop and minimum number of grains per spike was produced in the plots where there was no application of zinc was done.

Interaction between varieties and zinc application method also showed significant variation. Maximum number of grains per spike (51.16) was produced in the plots where wheat variety Faisalabad-2008 was sown and zinc was applied in both soil before planting and foliar application of zinc at later stages, followed by (50.53) in plots where Faisalabad-2008 was sown and zinc was applied through foliar application, (49.56) in plots where Punjab-2011 was sown and zinc was applied in both soil before planting and foliar application of zinc at later stages. Minimum number of grains per spike (39.63) was produced in the plots where Punjab-2011 was sown and no zinc was applied.

This is quite common observation that there is very close relationship between number of spikelets per spike and number of grains per spike. With increase in number of spikelets per spike there will be increase in number of grains per spike. With the application of zinc there is increase in grain setting is noticed due its involvement in processes such as pollination and fertilization due to their direct influence on formation of pollen tube [11] [12]. Zinc deficiency causes 
poor pollination and fertilization, which is the cause of low grain formation in wheat. These results are in line to the findings of [13] who reported that foliar application of zinc at lateral growth stages of wheat significantly enhances grains per spike. These findings are in alliance to the results of [14] who concluded that application of micronutrients significantly enhances the number of grains per spike; same type of findings was reported by [15].

\subsection{0-Grain Weight (g)}

The yield potential of any variety is determined by means of grain weight. The grain weight is vital yield contributing factor for considering the yield potential of wheat. The data presented in table depicts that there is a significant variation among varieties in case of 1000 -grain weight. Maximum 1000-grain weight (33.81 g) was recorded in Faisalabad-2008 and minimum 1000-grain weight (26.29 g) was produced by Punjab-2011.

In case of zinc application methods there was also significant relation noticed. Maximum 1000-grain weight (34.16 g) was recorded in the plots where zinc was applied both in soil before planting and foliar application on later stages, followed by $(29.86 \mathrm{~g})$ in plots where zinc was applied in soil before planting, $(29.65$ g) in plots where zinc is applied through foliar application method, and minimum 1000-grain weight $(26.53 \mathrm{~g})$ was recorded in the plots where there no zinc was applied. Interactions between varieties and zinc application methods also found to be significant. Maximum 1000-grain weight (38.76 g) was recorded in the plots where Faisalabad-2008 was sown and zinc was applied both in soil before planting and foliar application on later stages, followed by $(35.16 \mathrm{~g})$ in plots where Faisalabad-2008 was sown and zinc was applied through foliar application, (33.46 g) in plots where Faisalabad-2008 was sown and zinc was applied in the soil before planting of wheat and minimum 1000-grain weight $(25.20 \mathrm{~g})$ was recorded in the plots where Punjab-2011 was sown and no zinc was applied.

Zinc plays an important role in synthesis of growth hormone, starch formation and maturation which increase the weight of seed [16]. Zinc application increase 1000-grain weight that might due to zinc that has high phloem mobility from leaves to roots, stem and developing grains [17]. The results of this research was found to be in li ne with the findings of [2] who concluded that 1000-grain weight in significantly increased due to application of zinc. [18] also concluded that 1000-grain weight significantly increases with application of zinc on wheat.

\subsection{Biological Yield (t·ha $\left.{ }^{-1}\right)$}

Biological is a very vital character that determines the growth of plant and has an important correlation with crop yield. Biological yield determines the comparative growth rate of plants as it reflected to net assimilation rate. Data presented in table describes that there is a significant variance present among the means of biological yield in case of varieties. Maximum biological yield $\left(10.32 \mathrm{t} \cdot \mathrm{ha}^{-1}\right)$ was 
recorded from plots where Faisalabad-2008 was sown. Minimum biological yield $\left(10.05 \mathrm{t} \cdot \mathrm{ha}^{-1}\right)$ was produced by Punjab-2011.

In case of zinc application methods a significant variation among the means is recorded. Maximum biological yield (11.93 thha ${ }^{-1}$ ) was recorded in plots where zinc was applied both in the soil before planting and foliar application on later stages, followed by $\left(10.78 \mathrm{t} \cdot \mathrm{ha}^{-1}\right)$ in the plots where zinc was applied through foliar application, $\left(9.63 \mathrm{t} \cdot \mathrm{ha}^{-1}\right)$ was produced by plots where zinc was applied in soil before planting the crop and minimum biological yield $\left(8.38 \mathrm{t} \cdot \mathrm{ha}^{-1}\right)$ was produced in plots where no zinc was applied.

Interaction among wheat varieties and zinc application methods was also found to be significant. Maximum biological yield $\left(12.07 \mathrm{t} \cdot \mathrm{ha}^{-1}\right)$ was produced in plots where Faisalabad-2008 is sown and zinc is applied both in the soil before planting and foliar application on later stages, which is at par with $\left(11.80 \mathrm{t} \cdot \mathrm{ha}^{-1}\right)$ in plots where Punjab-2011 was sown and zinc was applied both in the soil before planting and foliar application on later stages and (10.93 th ha $\left.{ }^{-1}\right)$ in plots where Faisalabad-2008 was sown and zinc was applied through foliar application. Minimum biological yield $\left(8.26 \mathrm{t} \cdot \mathrm{ha}^{-1}\right)$ was produced in plots where Punjab-2011 was sown and no zinc was applied.

Zinc may be endorsed increased photosynthesis, initial growth, nitrogen fixation which encourages biological yield. These finding are in line to results of [2] who testified that application of zinc on later growth stages of wheat enhances the biological yield. [19] also found similar results who observed that application of micronutrients on later growth stages of wheat significantly increases biological yield.

\subsection{Grain Yield (t·ha-1)}

Grain yield is an ultimate goal and facilitate the evaluation to check out the effectiveness of all the treatments and hence considered most important parameter. It is an absolute product of final mechanisms, physiological and morphological processes occurring in plants during growth and development. Data that is presented in table depicts that there is a significant relationship between means of both varieties in terms of grain yield. Maximum grain yield $\left(5.00 \mathrm{t} \cdot \mathrm{ha}^{-1}\right)$ was produced by Faisalabad-2008 and minimum grain yield $\left(4.24 \mathrm{t} \cdot \mathrm{ha}^{-1}\right)$ was produced by Punjab-2011.

In case of zinc application methods significant variation among means was noticed. Maximum grain yield $\left(6.00 \mathrm{t} \cdot \mathrm{ha}^{-1}\right)$ was produced in the plots where zinc was applied both in soil before planting of and foliar application on later growth stages, followed by $\left(5.03 \mathrm{t} \cdot \mathrm{ha}^{-1}\right)$ in the plots where zinc is applied through foliar application and $\left(4.16 \mathrm{t} \cdot \mathrm{ha}^{-1}\right)$ in plots where zinc is applied in the soil planting of the crop. Minimum grain yield $\left(4.00 \mathrm{t} \cdot \mathrm{ha}^{-1}\right)$ was produced in the plots where no zinc was applied.

Interaction among varieties and zinc application methods are also found to be significant. Maximum grain yield (5.36 tha ${ }^{-1}$ ) was observed in plots where Punjab-2011 was sown and zinc was applied both in soil before planting of and foliar 
application on later growth stages, which is at par with $\left(5.20 \mathrm{t} \cdot \mathrm{ha} \mathrm{a}^{-1}\right)$ produced in plots where Faislabad-2008 was sown and zinc was applied both in soil before planting of and foliar application on later growth stages and $\left(5.53 \mathrm{t} \cdot \mathrm{ha}^{-1}\right)$ in plots where Faisalabad-2008 was sown and zinc was applied through foliar application. Minimum grain yield $\left(3.13 \mathrm{t} \cdot \mathrm{ha}^{-1}\right)$ was produced in the plots where Punjab-2011 was sown and no zinc was applied. Availability of micronutrients causes increase in the yield of crops. This increase of yield may be due to the abundant efficiency of enzyme activities which influence plant pigments because zinc is an important component of all classes of enzymes [20]. [21] 24\% - 38\% yield can be increased by the application of zinc as compared to controlled plots. [22] stated that grain yield was increased significantly by application of zinc. These results are in line to conclusions made by [2] and [19], both stated that increase in yield is observed when zinc is applied at lateral growth stages.

\subsection{Grain Zinc Contents (mg.kg-1)}

Zinc is one of the most important to all form of life such as plants, animals and humans. Risk of zinc deficiency is quit a concerning problem as zinc is essential in working of more than 100 enzymes which contributes towards the fact that more the zinc contents in the higher will be quality of that grain. Data presented in table depicts that there is significant variance present among varieties in case grain zinc contents. Maximum grain zinc contents $\left(25.68 \mathrm{mg} \cdot \mathrm{kg}^{-1}\right)$ observed in the grains produced by Faisalabad-2008 and minimum grain zinc contents $\left(25.30 \mathrm{mg} \cdot \mathrm{kg}^{-1}\right)$ was observed in grain produced by Punjab-2011.

In case of zinc application methods, significant variation is present among means of grain zinc contents. Maximum grain zinc contents $\left(33.11 \mathrm{mg} \cdot \mathrm{kg}^{-1}\right)$ was noticed in plots where zinc was applied both in soil before planting and foliar application at later stages, followed by $\left(27.57 \mathrm{mg} \cdot \mathrm{kg}^{-1}\right)$ in the plots where zinc was applied only through foliar application and $\left(22.76 \mathrm{mg} \cdot \mathrm{kg}^{-1}\right)$ in the plots where zinc was applied in the soil before planting. Minimum grain zinc contents $\left(18.57 \mathrm{mg} \cdot \mathrm{kg}^{-1}\right)$ were observed in the plots where no zinc was applied.

Interaction among varieties and zinc application method was non-significant. Maximum grain zinc contents $\left(33.26 \mathrm{mg} \cdot \mathrm{kg}^{-1}\right.$ ) was observed in plots where Faisalabad-2008 was sown and zinc was applied both in soil before planting and foliar application at later growth stages, this is at par with $\left(32.96 \mathrm{mg} \cdot \mathrm{kg}^{-1}\right)$ observed in grains from plots where Punjab-2011 was sown and zinc was applied both in soil before planting and foliar application at later growth stages. Minimum grain zinc contents $\left(18.46 \mathrm{mg} \cdot \mathrm{kg}^{-1}\right.$ ) were noticed in the plots where Punjab-2011 was sown and no zinc was applied.

These results support the finding made by [23] who reported that application of zinc increase grain zinc contents significantly among different wheat varieties.

\subsection{Grain Protein Contents (\%)}

Protein is most vital character of grain that describes it quality. Protein is required in large amount by our body so, the quality of the grain will be better 
with increase in protein contents of grain. A good portion of grain produce is consumed by poultry and livestock animals. So, there is need of improvement in quality of grain in terms of protein. Data presented in table depicts that there is a significant variation present among means of varieties in terms of protein contents. Maximum protein contents $(9.80 \%)$ were observed in grains produced by Faisalabad-2008. Minimum grain contents (9.51\%) were observed in grains produced from Punjab-2011.

The means in terms of protein contents varied significantly in case of zinc application methods. Maximum protein contents (10.1\%) was observed in plots where zinc was applied both in the soil before planting and foliar application on later stages, which is at par with (9.68\%) observed in the grains from plots where zinc was applied only by foliar application. Minimum grain protein contents (9.20\%) were observed in grains obtained from plots where no zinc was applied.

The interactions between means of varieties and zinc application methods in terms of grain protein contents were found to be insignificant. Maximum grain protein contents $(10.26 \%)$ was notices in grains obtained from the plots where Faisalabad-2008 was sown and zinc was applied both in the soil before planting and foliar application on later stages, which is at par with (9.93\%) in the grains form plots where Punjab-2011 was sown and zinc was applied both in the soil before planting and foliar application on later stages. Minimum grain protein contents $(9.13 \%)$ were observed in grains from plots where Punjab-2011 was sown and no zinc was applied.

These results are in line to the findings of [23] who declared that application of zinc significantly increases grain protein contents.

\section{References}

[1] Govt. of Pakistan. (2015) Economic Survey of Pakistan 2014-15. Ministry of Food, Agriculture and Livestock (Federal Bureau of Statistics), Islamabad, 11-26.

[2] Ali, S., Khan, A.R., Mairaj, G., Fida, M. and Bibi, S. (2008) Assessment of Different Crop Nutrient Management for Yield Improvement. Australian Journal of Crop Science, 2, 150-157.

[3] Rakkiyappan, P. and Thangavelu, S. (2000) Effect of Iron on Ratoon Crops of Six Sugarcane Varieties Grown in Iron Deficient Soil. Proceedings of International Conference on Management of Natural Resources for Sustainable Agricultural Production in the 21 st Century, 11-14 February 2000, New Dehli, 266-268.

[4] Bell, R.W. and Dell, B. (2008) Micronutrients for Sustained Food, Feed, Fiber and Bioenergy Production. International Fertilizer Industry Association, Paris.

[5] Alloway, B.J. (2008) Zinc in Soils and Crop Nutrition. 2nd Edition, International Fertilizer Industry Association, Paris.

[6] Imtiaz, M., Rashid, A., Khan, P., Memon, M.Y. and Aslam, M. (2010) The Role of Micronutrients in Crop Production and Human Health. Pakistan Journal of Botany, 42, 2565-2578.

[7] Cakmak, I. (2008) Enrichment of Cereal Grains with Zinc: Agronomic or Genetic Biofortification? Plant Soil, 247, 3-24. https://doi.org/10.1023/A:1021194511492

[8] Yilmaz, A., Ekiz, H., Torun, B., Gultekin, I., Karanlik, S., Bagci, S.A. and Cakmak, I. 
(1997) Effect of Different Zinc Application Methods on Grain Yield and Zinc Concentration in Wheat Cultivars Grown on Zinc-Deficient Calcareous Soils. Journal of Plant Nutrition, 20, 461-471. https://doi.org/10.1080/01904169709365267

[9] Asad, A. and Rafique, R. (2000) Effect of Zinc, Copper, Manganese, and Boron on the Yield and Yield Components of Wheat Crop in Tehsil Peshawar. Pakistan Journal of Biological Sciences, 3, 1615-1620. https://doi.org/10.3923/pjbs.2000.1615.1620

[10] Hussain, N., Khan, M.A. and Javed, M.A. (2005) Effect of Foliar Application of Plant Micronutrients Mixture on Growth and Yield of Wheat. Pakistan Journal of Biological Sciences, 8, 1096-1099. https://doi.org/10.3923/pjbs.2005.1096.1099

[11] Kaya, C. and Higgs, D. (2002) Response of Tomato (Lycopersicon esculentum L.) Cultivars to Application of Zinc When Grown in Sand Culture at Low Zinc. Scientia Horticulturae, 93, 53-64. https://doi.org/10.1016/S0304-4238(01)00310-7

[12] Panday, N., Pathak, G.C. and Sharma, C.P. (2006) Zinc Is Critically Required for Pollen Function and Fertilization in Lentil. Journal of Trace Elements in Medicine and Biology, 20, 89-96. https://doi.org/10.1016/j.jtemb.2005.09.006

[13] Khan, M.B., Farooq, M., Hussain, M., Shahnawaz and Shabbir, G. (2010) Foliar Application of Micronutrients Improves the Wheat Yield and Net Returns. International Journal of Agriculture and Biology, 12, 953-956.

[14] Chaudry, E.H., Timmer, V., Javed, A.S. and Siddique, M.T. (2007) Wheat Response to Micronutrientsin Rain-Fed Areas of Punjab. Soil Environment, 26, 97-101.

[15] Nadim, M.A., Awan, I.U., Baloch, M.S., Khan, E.A., Naveed, K. and Khan, M.A. (2012) Response of Wheat to Different Micronutrient and Application Method. Journal of Animal and Plant Sciences, 22, 113-119.

[16] Sarkar, D., Mandal, B. and Kundu, M.C. (2007) Increasing Use Efficiency of Boron Fertilizer by Rescheduling the Time and Methods of Application in Crops in India. Plant Soil, 301, 77-85. https://doi.org/10.1007/s11104-007-9423-1

[17] Rengel, Z. (2001) Genotypic Differences in Micronutrient Use Efficiency in Crops. Communications in Soil Science and Plant Analysis, 32, 1163-1186. https://doi.org/10.1081/CSS-100104107

[18] Torun, A., Itekin, I.G.A., Kalayci, M., Yalmiz, A., Eker, S. and Cakmak, I. (2001) Effects of Zinc Fertilization on Grain Yield and Shoot Concentration of Zinc, Boron and Phosphorus of 25 Wheat Cultivars Was Grown on Zinc Deficient and Boron Toxic Soil. Journal of Plant Nutrition, 2, 1817-1829. https://doi.org/10.1081/PLN-100107314

[19] Khan, M.A., Fuller, M.P. and Baluch, F.S. (2008) Effect of Soil and Applied Zinc Sulphate on Wheat Grown on Calcareous Soils in Pakistan. Cereal Research Communications, 36, 571-582. https://doi.org/10.1556/CRC.36.2008.4.6

[20] Malakouti, M.J. (2007) Zinc Is Neglected Element in Life Cycle of Plants: A Review. Middle Eastern and Russian Journal of Plant Science and Biotechnology, 1, 1-12.

[21] Yaseen, M., Ahmad, W., Arshad, M. and Ali, Q. (2011) Response of Wheat to Foliar Feeding of Micronutrients. IJA VMS, 5, 209-220. https://doi.org/10.5455/ijavms.20110601090456

[22] Maqsood, M., Rahmatullah, A., Kanwall, S., Aziz, T. and Ashraf, M. (2009) Evaluation of Zinc Distribution among Grain and Straw of Twelve Indigenous Wheat Genotypes. Pakistan Journal of Botany, 41, 225-231.

[23] Ranjbar, G.A. and Bahmaniar, M.A. (2007) Effects of Soil and Foliar Application of Zinc Fertilizer on Yield and Growth Characteristics of Bread Wheat Cultivars. Asian Journal of Plant Sciences, 6, 1000-1005.

https://doi.org/10.3923/ajps.2007.1000.1005 